\title{
Simultaneous Occurrence of Xanthine Oxidase and Sulfite Oxidase Deficiency. A Molybdenum Dependent Inborn Error of Metabolism?
}

\author{
C. van der HEIDEN, F. A. BEEMER, W. BRINK, S. K. WADMAN and M. DURAN \\ University Children's Hospital "Het Wilhelmina Kinderziekenhuis" Nieuwe Gracht 137, \\ Utrecht, The Netherlands
}

In a 3-week old female child with clinical features including neurologic abnormalities and lens dislocation, xanthinuria co-existed with increased excretion of sulfur compounds (sulfite, S-sulfocysteine, taurine and thiosulfate). Low xanthine oxidase and absent sulfite oxidase activities were found on liver biopsy. No abnormality was detected in either parent. Both the above enzymes are mblybdenum-flavoproteins. Normal serum molybdenum concentration seemed to rule out dietary deficiency or impaired absorption. A defect in the incorporation of the metal into flavoproteins is postulated in this case.

HEREDITARY XANTHINURIA HAS BEEN DESCRIBED to be a benign genetic disorder, due to a gross deficiency of xanthine oxidase. Biochemically it is characterized by hypouricemia, hypouricosuria and increased serum and trinary oxypurines (xanthine and hypoxanthiner. Except for urolithiasis and myopathy, due to accumulation of oxypurines in the muscles ${ }^{1}$ this disorder is rather asymptomatic. Reviews of well documented xanthinuric patients are given in the literature ${ }^{2,3,4}$. A very rare genetic disorder of cysteine metabolism is sulfituria, caused by sulfite oxidase deficiency, The observed clinical symptoms are remarkably similar in all patients: mental retardation, severe neurological abnormalities, lens dislocation. The patients are biochemically marked by an elevated excretion of sulfite, thiosulfate, taurine and S-sulfocysteine, but a low sulfate excretion. At the age of 3 weeks a baby girl was admitted to our hospital because of feeding difficulties. Other clinical symptoms observed at admission were: severe neurologic abnormalities, lens dislocation of the eyes and dysmorphic symptoms of the head. Biochemically, a simultaneous occurrence of xanthinuria and sulfituria was established.

Enzyme studies were carried out. Only small differences could be ascertained between some kinetic properties of xanthine oxidase and sulfite oxidase originating from human and animal tissues. In Table 1 these data are summarized. So the method developed with animal tissue material, was also suitable for measuring activities of both enzymes in human tissues. In our patient, xanthine oxidase determined in a jejunal biopsy specimen was absent, and in liver amounted to only $6 \%$ of the mean control value. In liver, sulfite oxidase could not be detected. Because two discrete genetic disorders in one patient seem unlikely, a primary defect influencing both enzymes should be more plausible as an explanation for this exceptional phenomenon. Xanthine oxidase as well as sulfite oxidase are both metallo-enzymes which have the trace element molybdenum (Mo) in common. The relationship between enzyme function and Mo-transport as well as incorporation of Mo in the active centres of the apoenzymes are still matters of speculation.

\section{METHODS}

Cysteine metabolites. Urinary sulfite was semiquantitatively determined with the Merckoquant ${ }^{\circledR}$ sulfite test (Merck, Darmstadt). In principle, Sörbo's method was used for determination of thiosulfate; the method of Miller et $a l^{8}$ for sulfate. The Technicon (TSM 1) automated column chromatograph, programmed for physiological fluids, was used for determining the acidic amino acids. The sample cartridges are loaded with a strong anion exchange resin (Technicon type $S$ chromobeads). Purines. Separation of urinary purines was done by two dimensional thin layer chromatography according to van Gennip et $a l^{9}$. Quantitative determination was performed according to the method earlier described ${ }^{10}$. Uric acid was measured enzymatically with uricase.

Enzymes. Xanthine oxidase (XO) was measured in a medium containing 87.5 umoles Tris buffer $\mathrm{pH} 9.0,1$ $\mu$ mole EDTA, 166 nmoles xanthine and $0.2 \mathrm{ml}$ enzyme solution up to final volume of $1 \mathrm{ml}$. The activity was calculated from the time-related uric acid formation. Uric acid was directly determined in the supernatant after stopping the incubation by heat inactivation ( 5 minutes, $100^{\circ} \mathrm{C}$ ) by adding a suitable catalytic concentration of uricase. For sulfite oxidase (SO) the kinetic method of Cohen and Fridovich" was used. For activity measurements of XO and SO in liver tissue, crude homogenates have to be dialyzed ( 15 hours, $4^{\circ} \mathrm{C}, 87.5 \mathrm{mmol} / 1$ Tris buffer pH 9.0 containing $1 \mathrm{mmol} / \mathrm{l}$ EDTA). Liver XO showed an increase of activity amounting to 2.2 . In SO activity measurement, dialysis is necessary to remove cytochrome-C reducing substances. A strong and rapid time related inactivation of $\mathrm{XO}$ in liver and intestine homogenates occurred when incubation was performed at $37^{\circ} \mathrm{C}$. Within an incubation period of 4 and 12 hours using liver and intestine homogenates respectively, the uric acid formation at $25^{\circ} \mathrm{C}$ proceeds linearly with time. Prolonged incubation results in loss of activity. A linear relationship could be established between the catalytic concentration of $\mathrm{XO}$ and the uric acid formed. Lactase, saccharase and maltase activity in intestinal biopsy specimens were calculated from the time related formation of glucose (lab. Dr. J.H. v.d. Kamer). The neutron activation method was used for determination of molybdenum (Dr. I. Lombeck, Düsseldorf) in serum.

\section{Results AND Discussion}

In our patient the uric acid was remarkably low (0.01-0.07 mmoles/l) in comparison with normals 
TABLE 1.

SOME PROPERTIES OF XANTHINE OXIDASE AND SULFITE OXIDASE IN ORGANS OF ANIMALS AND HUMANS

\begin{tabular}{|c|c|c|c|c|c|c|}
\hline Enzyme & Species & Organ & pH-optimum & \multicolumn{2}{|c|}{$\mathrm{Km}\left(\times 10^{-6} \mathrm{~mol} / 1\right)$} & Thermostablity \\
\hline & & & & Xanthine & Sulfite & \\
\hline Xanthine oxidase & $\begin{array}{l}\text { Ox } \\
\text { Rat } \\
\text { Human' } \\
\text { Human' }\end{array}$ & $\begin{array}{l}\text { liver } \\
\text { intestine } \\
\text { intestine } \\
\text { intestine }\end{array}$ & $\begin{array}{l}8.5 \\
9.5 \\
8.8 \\
8.8\end{array}$ & $\begin{array}{l}25.7\left(25^{\circ} \mathrm{C}, 1 \mathrm{~h}\right) \\
16.7\left(25^{\circ} \mathrm{C}, 1 \mathrm{~h}\right) \\
20.7\left(25^{\circ} \mathrm{C}, 3.5 \mathrm{~h}\right) \\
18.3\left(25^{\circ} \mathrm{C}, 3.5 \mathrm{~h}\right)\end{array}$ & E & $\begin{array}{l}<37^{\circ} \mathrm{C} \\
<37^{\circ} \mathrm{C} \\
<37^{\circ} \mathrm{C} \\
<37^{\circ} \mathrm{C}\end{array}$ \\
\hline Sulfite oxidase & $\begin{array}{l}\text { Rat } \\
\text { Human }{ }^{1} \\
\text { Human }\end{array}$ & $\begin{array}{l}\text { liver } \\
\text { liver } \\
\text { liver }\end{array}$ & $\begin{array}{l}8.5 \\
8.8 \\
9.0\end{array}$ & Z & $\begin{array}{l}\overline{28.9} \\
28.9\end{array}$ & $<\overline{45^{\circ} \mathrm{C}}$ \\
\hline
\end{tabular}

TABLE 2.

XANTHINE OXIDASE AND SULFITE OXIDASE ACTIVITY IN A PATIENT SHOWING THE SIMULTANEOUS OCCURRENCE OF XANTHINURIA AND SULFITURIA AND IN CONTROLS IN RELATION TO SOME REFERENCE ENZYMES.

\begin{tabular}{|c|c|c|c|c|c|}
\hline \multirow[t]{3}{*}{ Enzyme } & \multirow[t]{3}{*}{ Organ } & \multicolumn{4}{|c|}{ Activity } \\
\hline & & \multicolumn{2}{|c|}{ Controls } & \multicolumn{2}{|c|}{ Patient } \\
\hline & & $\begin{array}{l}\text { nmol/hour/mg } \\
\text { w.w. }\end{array}$ & $\underset{\text { protein }}{\mathrm{nmol} / \mathrm{hour}}$ /mg & $\begin{array}{l}\text { nmol/hour/mg } \\
\text { w.w. }\end{array}$ & $\underset{\text { protein }}{\mathrm{nmol} / \mathrm{hour} / \mathrm{mg}}$ \\
\hline 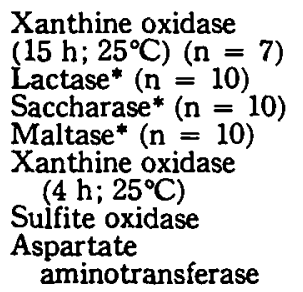 & $\begin{array}{l}\text { intestine } \\
\text { intestine } \\
\text { intestine } \\
\text { intestine } \\
\text { liver } \\
\text { liver } \\
\text { liver }\end{array}$ & $\begin{array}{l}1.6(0.6-3.1)^{\circ 0} \\
261(90-564) \\
413(198-786) \\
1374(792-2690) \\
1.2 ; 0.9 ; 4.0 ; 0.4 \\
46.5 ; 26.4 ; 61.8 ; 30.0 \\
1.4 ; 2.1 ; 3.4 ; 1.5\end{array}$ & $\begin{array}{c}16.4(7.6-30.0) \\
- \\
- \\
16.7 ; 14.0 ; 37.2 ; 5.5 \\
670 ; 410 ; 566 ; 366 \\
20.3 ; 32.6 ; 31.1 ; 19.2\end{array}$ & $\begin{array}{c}0 \\
432 \\
360 \\
1206 \\
0.04 \\
0 \\
4.3\end{array}$ & $\begin{array}{l}0 \\
\bar{Z} \\
\overline{0.34} \\
0 \\
33.8\end{array}$ \\
\hline
\end{tabular}

*lab of gastroenterology (Dr. J. H. v.d. Kamer)

- w.w.: wet weight

- ( ) : range

(0.12-0.35 mmoles/1). In urine, xanthine (3.7-7.6 mmoles/g. creatinine) and hypoxanthine (0.1-1.1 mmoles/g. creatinine) were significantly increased.

In normal subjects urinary xanthine and hypoxanthine amounted to 0.06-0.25 and 0.02-0.07 mmoles/g. creatine respectively ${ }^{12}$. Usually the urate excretion was less than 0.3 mmoles $/ g$. creatinine. Compared to some random controls, this value is low. Urate excretion has been recently demonstrated to be age dependent ${ }^{13}$. During early childhood its clearance is elevated, but decreases progressively with advancing age, because the urate clearing mechanism in early childhood seems to differ from that in adults. The low urate, together with the elevated xanthine and hypoxanthine in the urine of our patient, pointed clearly to XO deficiency which was established by $\mathrm{XO}$ activity measurements in liver and intestinal biopsy specimens (see Table 2). Normal activities of some reference enzymes have shown the validity of the biopsy specimens. The excretory pattern of sulfur-compounds in our patient is characteristic of SO deficiency. The following cysteine metabolites, expressed in mmoles/g creatinine, were found to be elevated in the urine: sulfite, up to 6 (normal: not present); S-sulfocysteine: 2.3-2.6 (normal: not present); taurine: 1.9-7.6 (normal $1.2 \mathrm{mmoles} / \mathrm{day}$ ) and thiosulfate: 0.80 (normal: $0.02 \mathrm{mmoles} / \mathrm{l}$ ). Urinary sulfate was decreased (1.9-13-7 mmoles/g creatinine) Sörbo and Öhman ${ }^{14}$ have established a sulfate-thiosulfate ratio amounting to 1000 in urines of healthy adults. If this ratio is also valid for early childhood, the strong deviation in the ratio (9.8) in our patient supports the presence of abnormal cysteine catabolism. In the patient's liver, SO activity could not be detected (see Table 2). Her parents did not demonstrate any significant biochemical abnormality of xanthine or cysteine metabolism. Although established by enzyme studies, a combined enzyme deficiency in one patient seems unlikely. A defective factor, which both enzymes have in common, has rather to be considered. Up to now only XO and SO have been demonstrated in human beings to be metalloflavo-enzymes requiring molybdenum (Mo) in their active centres ${ }^{15-17}$. Nitroreductase activity of aldehyde oxidase, also a molybdoflavoprotein, has been assessed in mammalian liver ${ }^{19}$. Its specificity seems to be poor because xanthine oxidase has a similar catalytic ability. In our patient no indications of a deficient aldehyde oxidase were found. In this respect, a human aldehyde oxidase, requiring $\mathrm{Mo}$ in its active centre for optimal activity, seems unlikely to be of high clinical relevance. Consequently investigations on aldehyde oxidase or its ability in reducing nitrocompounds have not been taken into consideration. A deficit of Mo in the diet as a reason of malfunctioning of $\mathrm{XO}$ 
and SO could be excluded, for the serum Mo-concentration $(1.7 \mathrm{nmol} / \mathrm{l})$ did not differ from that in a control $(1.0 \mathrm{nmol} / \mathrm{l})$. Other possibilities might be a defective synthesis or dysfunction of (a) the Mocarrier protein or (b) the enzyme activating co-factor, necessary to incorporate $M o$ in the active centres of the apoenzymes. Experiments in this field are in progress.

\section{REFERENCES}

1. Parker, R., Snedden, W. and Watts, R.W.E. Biochem. J. 116, 317, 1970.

2. Desbois, J.C., Cartier, P., Petyst, O., Allaneau, C. and Herrault, A. Ann. Pediat. 24, 551, 1977.

3. Dwosh, I.L., Roncari, D.A.K., Marliss, E. and Fox, I.H. J. Lab. Clin. Med. 90, 153, 1977.

4. Cartier, P. and Perigno, J.L. Nouv. Press. Med. 7, $7,1381,1978$.

5. Irreverre, F., Mudd, S.H., Heizer, W.D. and Laster, L. Biochem. Med. 1, 187, 1967.

6. Shih, V.E., Abroms, I.F., Johnson, J.L., Carney, M., Mandell, R., Robb, R.M., Clonerty, J.P. and Rajagopalan, K.V. New Engl. J. Med. 257, 1022, 1977.
7. Söbo, B. Biochim. Biophys. Acta 23, 412, 1957.

8. Miller, E., Hlad jr. C.J., Levine, A., Holmes, J.H. and Elrick, H. J. Lab. Clin. Med. 62, 710, 1963.

9. Gennip van, A.H., Noordenburg-Huistra van, D.Y., de Bree, P.K. and Wadman, S.K. Clin. Chim. Acta 86, 7, 1978.

10. Stoop, J.W., Zegers, B.J.M., Hendrickx, G.F.M., Siegenbeek van Heukelom, L.H., Staal, G.J.E., de Bree, P.K., Wadman, S.K. and Ballieux, R.E. New Engl. J. Med. 296, 651, 1977.

11. Cohen, N.J. and Fridovich, J. J. Biol. Chem. 246, $359,1971$.

12. Balis, M.E., Krakoff, I.H., Berman, P.H. and Dancis, J. Science 156, 1122, 1967.

13. Bruder Stapleton, F., Lindshaw, M.A., Hassanein, K. and Gruskin, A.B. J. of Pediat. 92, 911, 1978.

14. Sörbo, B. and Öhman, S. Scand. J. Clin. Lab. Invest. $38,521,1978$.

15. Avis, P.G., Bergel, F. and Bray, R.C. J. Chem. Soc. $1100,1955$.

16. Johnson, J.L., Cohen, H.J. and Rajagopalan, K.V. J. Biol. Chem. 249, 5046, 1974.

17. Johnson, J.L., Wand, W.R., Cohen, H.J. and Rajagopalan, K.V. J. Biol. Chem. 249, 5056, 1974.

18. Wolpert, M.K., Althaus, J.R. and Johns, D.G. J. Pharmacol. Exp. Ther. 185, 202, 1973.

\title{
Genetic Disease, Future Exploration in Clinical Enzymology
}

\section{ERICH KAISER}

\author{
Department of Medical Chemistry, University of Vienna, Vienna, Austria
}

THERE IS NO DOUBT THAT WE ARE LIVING in an age of prevention, and the treatment of a disease or the amelioration of social problems is considered more and more as a secondary thrust of medical efforts. Genetic counseling is an important effort in this direction. Nowadays clinical enzymology offers means for prenatal diagnosis of genetic diseases of the fetus in utero, and for postnatal detection of inherited disorders in the newborn child. In addition methods of clinical enzymology are now routinely used in the detection of heterozygous carriers for many genetic diseases.

1.The most important impetus for prenatal diagnosis of genetic diseases came from the introduction of diagnostic amniocentesis. The study of amniotic fluid or of amniotic cells for prenatal diagnosis of genetic diseases is based on two main assumptions and several practical considerations. The material used for analysis must be of fetal origin and the genetic defect must be expressed in amniotic cells. The practical aspects of prenatal diagnosis include the selection of cases and the appropriate time of amniocentesis. Indications for diagnostic amniocentesis include maternal age in excess of 35 years, a family history or particularly a previous birth to the present mating of a child suffering from one of the diseases which can be diagnosed from amniotic cells and the prior identification of at risk mating by the detection of the gene of a recessively transmitted disease in both parents. It is now commonly recommended to perform amniocentesis be- tween 14 and 16 weeks of gestation. Amniocentesis which is preferably done by the transabdominal route, should be routinely preceded by ultrasound studies giving information on placental localization, diameter of the fetal head and multiple fetuses.

1.1. Analysis of amniotic fluid and of uncultured amniotic cells possesses the big advantage of the availability of results within a few days following amniocentesis. However, it has been demonstrated that the use of amniotic fluid or of uncultured cells supplies us with many false results. The most common reasons for this handicap are: problems in the separation of amniotic cells from maternal blood cells, the presence of maternal proteins in amniotic fluid and the fact that most uncultured cells are $d y-$ ing or dead. In addition enzymes in amniotic fluid are partly inactivated by dilution or by the presence of inhibitors.

1.2. Analysis of cultured amniotic cells suffers mainly from the fact that enzymatic techniques require large amounts of amniotic cells. This means that either amniocentesis must be performed at a relatively late stage of pregnancy or that cells must be cultivated for a rather long period. This disadvantage was partly overcome by the introduction of new microtechniques allowing quantitative determinations of enzyme activity in single isolated cells'. Another highly sensitive technique is based on the cooperation or lysosomal acid hydrolases and alkaline phosphatase (AP) in the intracellular digestion of biomolecules'. Whenever a biomolecule is 